\title{
ФАГОЦИТАРНА АКТИВНІСТЬ НЕЙТРОФІЛІВ У ХВОРИХ НА ГОСТРИЙ ГЕПАТИТ В
}

\author{
ДУ «Інститут мікробіології та імунології ім. І.І. Мечникова НАМН України», Харків
}

Проникаючи в організм, інфекційні агенти стикаються з вродженими імунними клітинами, серед яких фрагоцити знаходяться на першій лінії захисту.

Мета роботи - вивчення фрункціонального стану поліморфрноядерних нейтрофрілів у крові хворих на гострий гепатит В (ГГВ) різного ступеня тяжкості у динаміці загальноприйнятого лікування та після призначення симбіотика.

Пацієнти і методи. Під спостереженням перебувало 108 хворих на ГГВ, від 18 до 69 років (середній

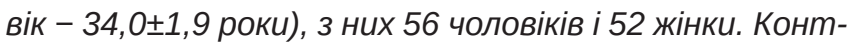
рольну групу склали 17 здорових осіб. Для оцінки фрагоцитарної активності нейтрофрілів (ФАН) визначали фрагоцитарний індекс нейтрофрілів (ФІН) і фрагоцитарне число нейтрофрілів (ФЧН) з періодами інкубації 30, 60 і 180 хв.

Результати. У хворих на ГГВ легкого ступеня тяжкості встановлено значну активацію поліморфноядерних нейтрофрілів впродовж активної фрази HBVінфрекції, що характеризується підвищенням рівнів ФІН і ФЧН в 1,1-1,8 разу та 1,5-1,9 разу відповідно порівняно $з$ контрольною групою.

У хворих із ГГВ середнього ступеня тяжкості у різні періоди хвороби відмічається значне пригнічення фрагоцитозу, що проявляється зменшенням кількості нейтрофрілів, які задіяні у фрагоцитарних реакціях (в 1,2-1,5 разу порівняно з контрольною групою). Втім, не зважаючи на значне пригнічення інтенсивності фагоцитозу, поглинаюча здатність нейтрофрілів у вказаних хворих підвищена або знаходиться на рівні здорових осіб.

Інтенсивність фрагоцитозу у хворих на ГГВ легкого і середнього ступеня тяжкості, що отримували симбіотик, була значно вищою, ніж у хворих, які лікувалися стандартною терапією, за рахунок збільшення кількості фрагоцитуючих нейтрофрілів у крові в 1,2-1,4 разу.

Висновки. Виявлено значні компенсаторні можливості нейтрофрілів, які здатні в умовах інтенсивного HBV навантаження підтримувати загальний баланс у фрагоцитарній системі. Включення симбіотика до спільної схеми терапії підвищує як інтенсивність фра- гоцитозу, так і регулює поглинаючі можливості нейтрофрілів у хворих на HBV-інфрекцію різного ступеня тяжкості.

Ключові слова: гострий гепатит B, фрагоцитоз, фрагоцитарний індекс нейтрофрілів, фрагоцитарне число нейтрофрілів, симбіотик.

HBV-інфекція є однією з глобальних проблем сучасної медицини, що підтверджується надзвичайною поширеністю та високою летальністю як від фуллінантного гепатиту, так і HBV-асоційованого цирозу печінки (ЦП) і гепатоцелюлярної карциноми (ГЦК).

Дослідження останніх років засвідчують важливу роль первинних імунних реакцій у противірусному захисті. Фагоцитоз (Ф) належить до вроджених, консервативних і постійних імунних процесів в організмі людини. Ф - одна із перших реакцій багатьох клітин організму у відповідь на проникнення різноманітних патогенів навколишнього середовища. Втім, єдиними клітинами, що володіють активним фагоцитозом, є нейтрофріли і моноцити, саме тому їх вважають спеціалізованими профресійними фагоцитами. Порівнюючи фрагоцитарні можливості цих клітин, виявилося, що антимікробна здатність нейтрофрілів вище, ніж у макрофрагів [1]. У зв'язку з цим нейтрофріли набувають прогресуючого статусу фрундаментальних фрагоцитарних імунних клітин [2]. Проте вважається, що фрагоцитарні реакції макрофрагів не задіяні в противірусному захисті організму, а обмежені в основному фрагоцитозом бактерій і грибів [3]. Можливо тому гранулоцити, до складу яких входять поліморфноядерні нейтрофріли, відокремлені від інших фрагоцитуючих клітин, що утворюють систему мононуклеарних фрагоцитів (МФС). Але разом з тим також відомо, що до складу гранул нейтрофрілів входять до 300 цитотоксичних метаболітів, дія яких спрямована на різні мікроорганізми [4]. В тому числі з'ясувалось, що багато з них спроможні знищувати віруси. Так, противірусну дію, ініційовану процесом фрагоцитозу, здатні проявляти такі компоненти поліморфноядерних нейтрофілів, як гідроксильний радикал $\left(\mathrm{HO}^{\circ}\right)$, міелопероксидаза, галоїдні іони, лактофрерин, оксид азоту (NO) і др. [5]. Іншим дже- 
релом мікробоцидних метаболітів, що утворюються в фрагосомах, є десрензіми, які активні щодо бактерій, грибів і багатьох оболонкових і безоболонкових вірусів [6]. Нещодавно було відкрито нову антимікробну стратегію в нейтрофрільному репертуарі - утворення позаклітинних пасток нейтрофрілів (NETs), які можуть захоплювати, нейтралізувати і вбивати різні бактерії і віруси [7].

Загальновідомий фракт зниження фрагоцитарної активності лейкоцитів при хронічних гепатитах (ХГ) і цирозі печінки, що, на думку дослідників, може бути спричинено впливом вірусної інфекції та ендогенної інтоксикації. Проте, за іншими даними, ураженню печінки сприяє підвищення концентрації антимікробних пептидів у зоні запалення, що обумовлено невідповідною активацією і порушенням повернення нейтрофілів у мікроциркуляцію. Це було підтверджено у різних дослідженнях, у тому числі і на експериментальній моделі трансгенних мишей, інфікованих HBV, у яких інгібування нейтрофрільної еластази призводило до поліпшення фрункції гепатоцитів [8]. Взагалі у літературі $€$ досить багато відомостей відносно реакції лейкоцитів при вірусних гепатитах, проте вони не завжди враховують сучасні дані про систему фагоцитозу; крім того, ці результати доволі розрізнені і навіть протилежні за своєю суттю. Водночас у дослідженнях М.T. Silva та ін. повідомляється, що макрофраги і нейтрофріли діють гуртом в реакціях вродженого імунітету як взаємодоповнюючі і спільні партнери єдиної ланки. Тому вчені запропонували додати нейтрофіли до МФС для об'єднання цих імунних клітин в єдину мієлоїдну фрагоцитарну систему (MYPS) [9].

Беручи до уваги вищевикладені дані і спираючись на твердження, що імунна система - це єдиний орган багатогранної системи в складі різних компонентів, від гармонічної взаємодії яких залежить результат імунної відповіді, в тому числі при вірусних інфекціях, нами вирішено провести дослідження фрагоцитарної активності нейтрофрілів у хворих на ГВ. Також відомо, що при багатьох вірусних захворюваннях первинні імунні реакції не ефективні або розвиваються з запізненням. Зокрема така закономірність притаманна при інорікуванні HBV [10]. В той же час відомо, що деякі пробіотичні мікроорганізми можуть стимулювати фрагоцитарні реакції [11]. Тому ми використовували у комплексній терапії хворих на ГГВ симбіотик, до складу якого входили Lactobacillus acidophilus i Bifidobacterium bifidum та додатковий комплекс біологічних полімерів: целюлоза, геміцелюлоза, пектин і сорбент лігнін.

Мета роботи - вивчення функціонального стану поліморфноядерних нейтрофілів у крові хворих на ГГВ різного ступеня тяжкості у динаміці загальноприйнятого лікування та після призначення симбіотика.

\section{Пацієнти і методи}

Під наглядом знаходилися 108 хворих на ГГВ, з них чоловіків 56 та жінок 52. Вік хворих від 18 до 69 років, у середньому становив $(34,0 \pm 1,9)$ роки. Усі інфріковані перебували на лікуванні в Обласній клінічній інфекційній лікарні м. Харкова, серед яких було 40 хворих з легким ступенем тяжкості і 68 - із середнім ступенем тяжкості. Діагноз ГГВ був встановлений у відповідності до стандартизованих протоколів діагностики і лікування інсрекційних хвороб на підставі даних анамнезу, клінічного та інструментального (ультразвукової діагностики) обстеження, з урахуванням біохімічних показників, які характеризують фрункціональний стан печінки. Для підтвердження вірусного ураження печінки досліджували сироватку крові хворих методом імуноферментного аналізу (ІФА) на специфрічні маркери гепатиту В та інші інфекційні захворювання. При виявленні в обстежених маркерів гепатитів C, D, А або мікст-інсекції, а також антитіл до ВІЛ, вони вилучалися з подальшого дослідження. Критерієм відбору хворих на ГГВ були такі маркери - HBsAg, anti-HBc IgM, сумарні anti-HBc, HBeAg, anti-HBe. Для додаткового підтвердження гострого інфекційного процесу використовували якісний аналіз ПлР на виявлення ДНК HBV. Хворі, в яких був діагностований хронічний ГВ, також були відсторонені від подальших досліджень.

Відповідно до мети дослідження усі хворі були розділені на 4 групи в залежності від тяжкості перебігу хвороби та методу лікування. 1 група склала 20 осіб, що мали легкий ступінь тяжкості і знаходилися на стандартному лікуванні, 2 група - 20 хворих з легким ступенем тяжкості, які окрім стандартного лікування додатково приймали симбіотик. Аналогічний розподіл був серед хворих середнього ступеня тяжкості: 3 група - 34 хворих, що лікувалися стандартною терапією, і 4 група - 34 хворих, які отримували симбіотик. Хворі, що приймали симбіотик, сформували основну групу. Відповідно у групу порівняння ввійшли хворі, які отримували базове лікування. Контрольна група (5) склала 17 здорових осіб.

Визначення параметрів фагоцитозу проводилося відповідно до рекомендацій В.Г. Передерія та співавт. [12] Визначали фагоцитарний індекс нейтрофрілів (ФІН; PІN) i фагоцитарне число нейтрофрілів (ФЧН; PNN). ФІН - це кількість фрагоцитуючих клітин на 100 нейтрофрілів, виділених із периферичної крові хворого (\%). ФІН характеризує інтенсивність фрагоцитозу. ФЧН - це середня кількість мікробних тіл, поглинутих 1 нейтрофрілом, що знаходиться в стадії фрагоцитозу. ФЧН характеризує поглинаючу здатність нейтрофрілів і розраховується в умовних одиницях.

Вивчали ФАН у хворих на ГГВ в динаміці захворювання в 2 етапи: у жовтяничному періоді і після призначення симбіотика (період реконвалесценції). Перший забір крові проводили у жовтяничному періоді ГГВ у фразу розвитку 
жовтяниці. Термін призначення симбіотика у хворих 2 та 4 групи склав 14 днів. Другий забір венозної крові у досліджуваних груп проводили через 5-7 днів після відміни симбіотика, що співпало з клінічною фразою зниження інтенсивності жовтяниці і початком періоду реконвалесценції.

Статистичну обробку отриманих результатів проводили за допомогою програми Statistica 10. Використовували параметричний дисперсійний аналіз (критерій Фішера), тест Шефоре для апостеріорних множинних порівнянь середніх значень показників та критерій Ст'юдента для пов'язаних змінних. Порівняння середніх значень показників у жовтяничний період (Icter.) здійснювали у групах, що визначалися ступенем тяжкості хвороби (легкий, середній) і контрольною групою. Порівняння середніх значень показників у періоді реконвалесценції (Conval.) здійснювали у групах, що визначалися ступенем тяжкості хвороби та методом лікування (стандартний - Standard), й із застосуванням симбіотика бісілакт екстра (НДВ “Аріадна", Україна) - (Ве). Описова статистика представлена у вигляді середнього арифметич-

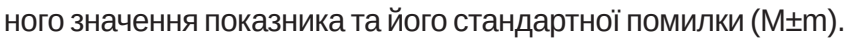
Відмінність вважали достовірною при р<0,05.

\section{Результати досліджень та їх обговорення}

Визначено, що показники активності фрагоцитозу у жовтяничному періоді статистично не відрізнялись між собою у 1 та 2 групах хворих (легкий ступінь тяжкості) та, відповідно, в обстежених осіб 3 та 4 груп (середній ступінь тяжкості). Але з'ясувалось, що у цей період ГГВ ФАН суттєво відрізняється залежно від ступеня тяжкості хвороби. Значне підвищення рівня ФІН визначено у хворих легкого ступеню тяжкості (групи 1 та 2) порівняно 3 хворими, які мали середній ступінь тяжкості хвороби (групи 3 та 4), а також порівняно з групою контролю (5). Так, у хворих 1 та 2 груп середнє значення ФІН-30 становить $(87,6 \pm 1,2) \%$, у хворих 3 та 4 груп ФІН-30 $(58,1 \pm 1,8) \%$. Наступні порівняння, ФІН-60 - $(89,3 \pm 1,8)$ i $(56,9 \pm 3,2) \%$; ФІН-180 - $(86,8 \pm 1,1)$ і $(49,3 \pm 2,8) \%$, відповідно різниця між групами статистично значима $(p<0,05)$. Також достовірно вищі показники інтенсивності фрагоцитозу були у 1 та 2 груп хворих при порівнянні їх з групою здорових осіб (5), в яких ФІН-30 - $(71,4 \pm 1,9) \%(p<0,05)$; ФІН-60 - $(73,9 \pm 1,3) \%,(p<0,04)$ і ФІН-180 - $(72,1 \pm 0,8) \%$, $(p<0,01)$ (мал. 1).

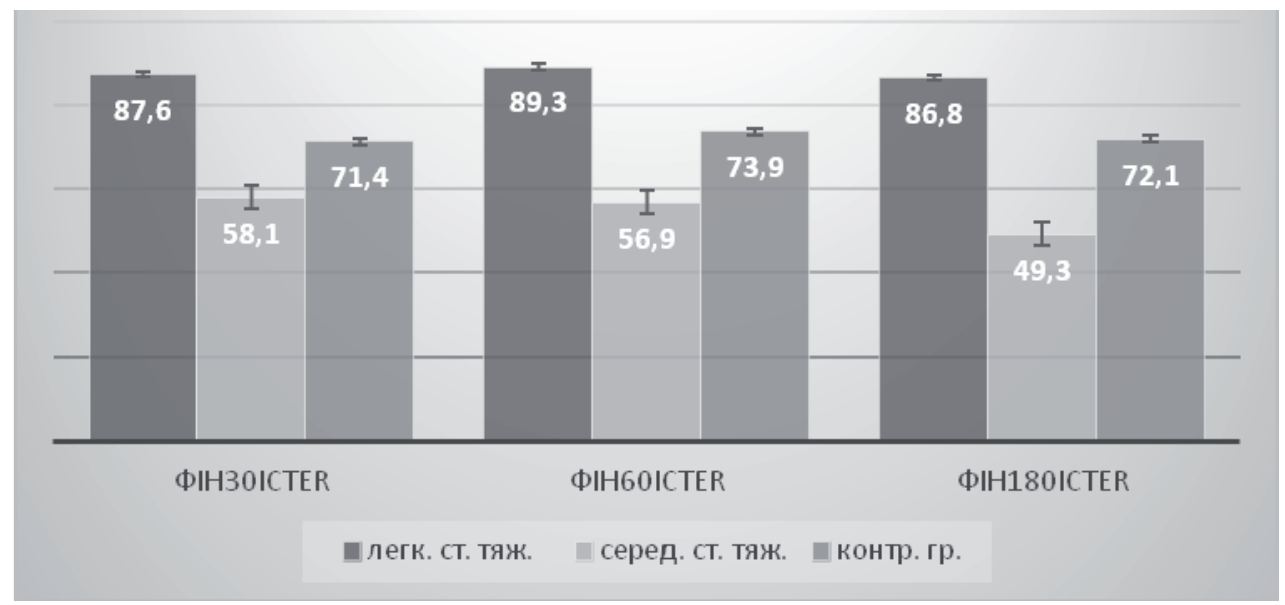

Мал. 1. ФІН (\%) у хворих на ГГВ у жовтяничному періоді.

Порівнюючи поглинаючі властивості фрагоцитів у хворих легкого ступеня тяжкості (1 і 2 групи) та хворих середнього ступеня тяжкості (групи 3 і 4) і групи контролю, з'ясувалось, що показники ФЧН були значно вищими в осіб, що мали легкий ступінь тяжкості хвороби.

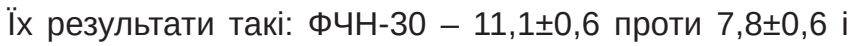

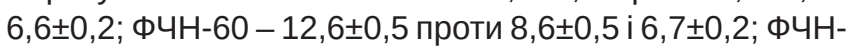

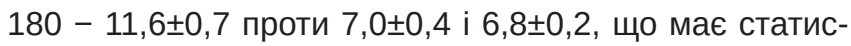
тичне підтвердження $(\mathrm{p}<0,05)$. У той же час, аналізуючи показники ФАН у хворих середнього ступеня тяжкості (групи 3 та 4) порівняно $з$ легким, було встановлено достовірне зниження ФЧН в усіх інтервалах інкубації (30, 60 і 180 хв) у хворих на HBV-інфекцію, тому $p<0,00$.
Рівні ФЧН-30 і ФЧН-180 у хворих 3 та 4 групи статистично не відрізнялися від групи 5, де ФЧН-30 - 6,6士0,2 і ФЧН-180 - 6,8 $\pm 0,2$, тому $(p<0,36)$ i $(p<0,95)$. Тоді як значення ФЧН-60 - 8,6士0,5 у хворих середнього ступеня тяжкості достовірно перевищує рівень групи контролю,

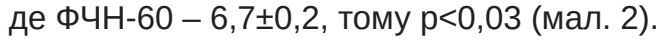

Спостерігаючи за фрагоцитозом у динаміці захворювання та після призначення симбіотика з'ясувалось, що фрагоцитарна реакція нейтрофілів має певну тенденцію, яка визначається ступенем тяжкості гепатита та пов'язана з прийомом симбіотика. Саме тому у дослідженні ми окремо розглядали відповідь вродженого неспецифрічного імунітету, враховуючи тяжкість перебігу хвороби. 


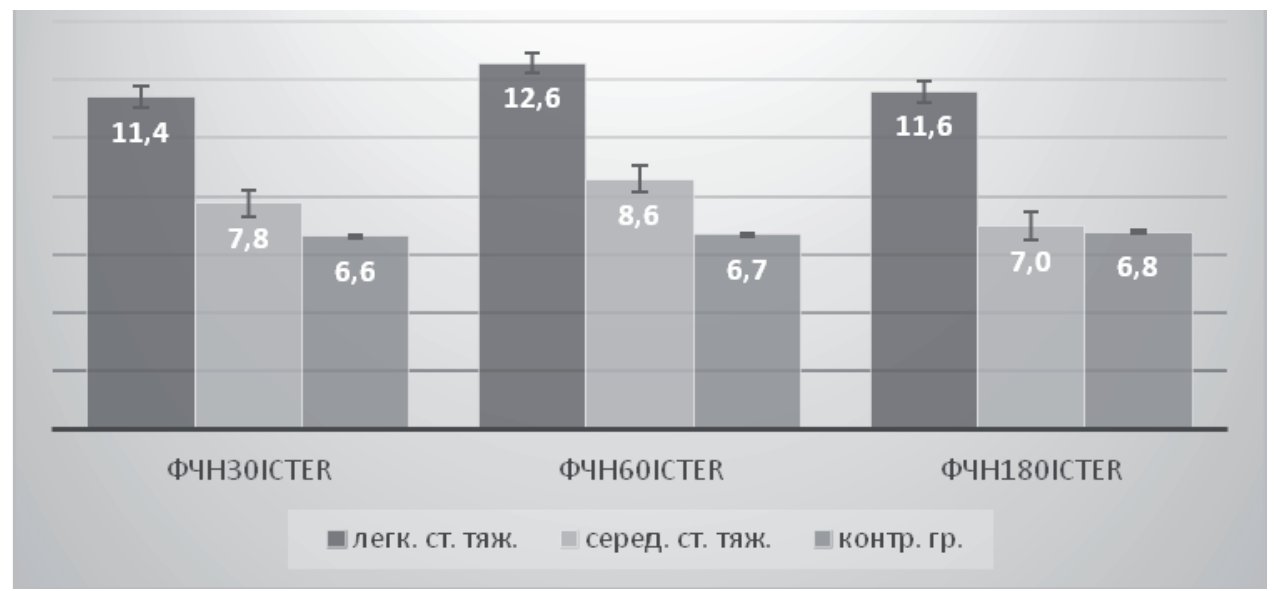

Мал. 2. ФЧН (\%) у хворих на ГГВ у жовтяничному періоді.

Порівнюючи ФАН у хворих легким ступенем тяжкості у періоді реконвалісценції, які знаходилися на стандартному лікуванні (група 1), і групою хворих після призначення симбіотика (група 2) та групою здорових осіб (5) встановлено, що нейтрофрільний фрагоцитоз був інтенсивніший у хворих, які приймали симбіотик. Зо-

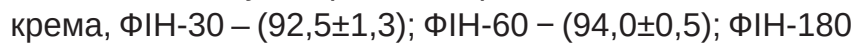
- $(91,1 \pm 1,3) \%$ у хворих 2 групи статистично відрізнявся від рівнів ФІН-30 - $(78,7 \pm 4,7)$; ФІН-60 - $(81,5 \pm 4,0)$ і ФІН-
180 - $(78,4 \pm 3,9)$ \% групи порівняння, та групи контролю, відповідно $р<0,01$.

Показники ФЧН у хворих групи 1 і у хворих групи 2 у періоді реконвалесценції виявилися такими: ФЧН-30

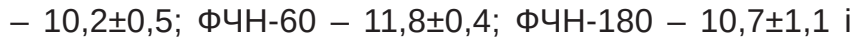


$11,2 \pm 0,6$; вони статистично не відрізнялися між собою $(p=1, p<0,3, p<0.9)$, однак їх рівень значно перевищував показники контрольної групи $(p<0,05)$ (мал. 3).

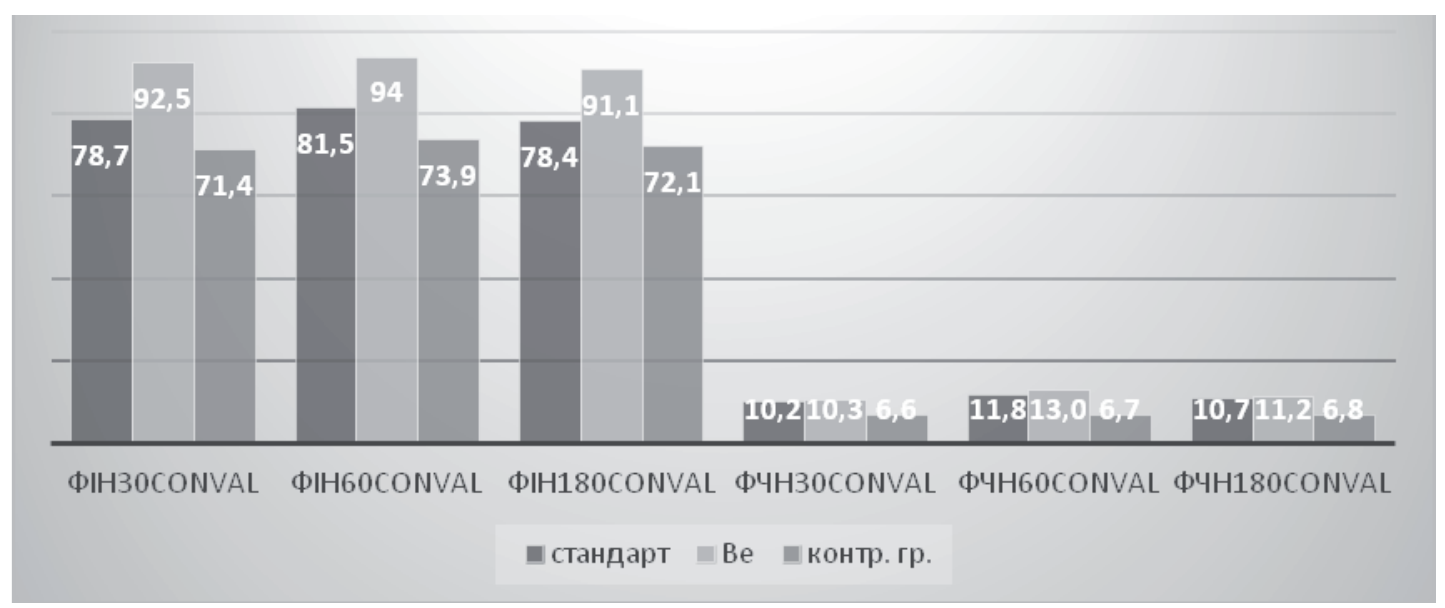

Мал. 3. ФАН (\%) у хворих на ГГВ легкого ступеня тяжкості після лікування.

У хворих середнього ступеня тяжкості фрагоцитарні реакції мали подальшу спрямованість. В усіх періодах дослідження фрагоцитозу (30, 60 і 180 хв) рівні ФІН у хворих, які отримували базову терапію (група 3), були нижчими за групу контролю. На противагу, показники ФІН у групі хворих, що приймали симбіотик (4), були значно вищі, ніж у групі 3, і корелювали з групою здорових осіб. Так у хворих, які додатково отримували симбіотик, ФІН-30 був $(66,9 \pm 3,0)$ проти ФІН-30
$(56,0 \pm 3,2) \%$ хворих, що лікувалися тільки базовою терапією, відповідно р<0,05. Показники ФІН-60 - $(80,4 \pm 2,6)$; ФІН-180 - $(67,4 \pm 1,7)$ групи 4 також достовірно відрізнялися від 3 групи, де ФІН-60 - $(63,1 \pm 3,3)$ і ФІН-180 $(48,3 \pm 3,0$, тому $(p<0,05)$. Різниця між показниками фрагоцитозу нейтрофрілів у групі 3 порівняно 3 групою 5 відповідала наступним статистичним висновкам $\mathrm{p}<0,05, \mathrm{p}<0,02$ і $\mathrm{p}<0,05$ (мал. 4). 
ОРИГІНАЛЬНІ ДОСЛІДЖЕННЯ

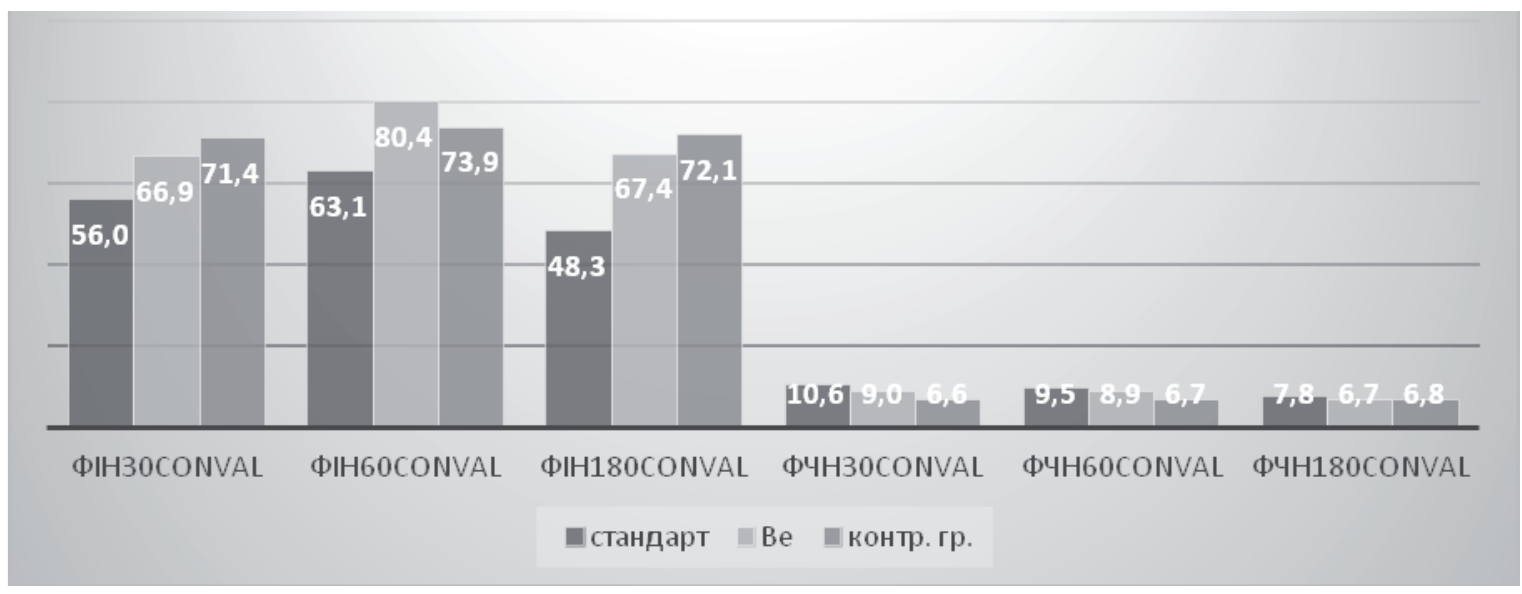

Мал. 4. ФАН (\%) у хворих на ГГВ середнього ступеня тяжкості після лікування.

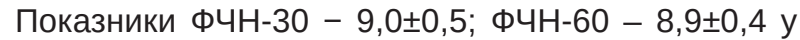
хворих, що приймали симбіотик (група 4), і ФЧН-30 -

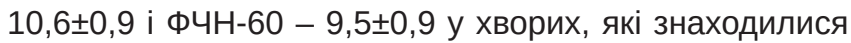
на стандартній терапії (група 3), достовірно не відрізнялися між собою, проте були статистично вищими, ніж у групі контролю (група 5), відповідно р<0,03 (порівнюючи групи 4 і 5) та р<0,05 (порівнюючи групи 3 і 5). Проте досліджуючи рівні ФЧН-180 у групах 4 та 3 і порівнюючи їх 3 групою $5(6,7 \pm 0,6 ; 7,8 \pm 0,7 ; 6,8 \pm 0,2)$, достовірної різниці між ними не було виявлено $(p=1, p<0,4)$ Необхідно зазначити, що показники ФЧН в основних групах і групах порівняння у періоді реконвалесценції статистично не відрізнялися між собою (мал. 4).

Обговорюючи отримані результати, можна констатувати, що поліморфноядерні нейтрофріли не залишаються інертними сторонніми клітинами в антивірусному процесі, вони задіяні при HBV-інфекції. Втім, яку роль відіграють нейтрофріли - мають безпосередньо противірусну дію або опосередковано беруть участь в елімінації вірусів, чи, навпаки, HBV використовує фрункціональні можливості фрагоцитів для реплікації і розповсюдження, - ще необхідно з'ясувати.

\section{Висновки}

1. У хворих на ГГВ легкого ступеня тяжкості встановлено значну активацію поліморфноядерних нейтрофрілів впродовж активної фрази HBV-інфекції, що характеризується підвищенням рівнів ФІН та ФЧН в 1,1-1,8 разу та 1,5-1,9 разу відповідно порівняно з контрольною групою.

2. У хворих з ГГВ середнього ступеня тяжкості у різні періоди хвороби відмічається значне пригнічення фрагоцитозу, що проявляється зменшенням кількості нейтрофілів, які задіяні у фрагоцитарних реакціях (в 1,21,5 разу порівняно з контрольною групою). Втім, незважаючи на це, поглинаюча здатність нейтрофрілів у вказаних хворих підвищена або знаходиться на рівні здорових осіб. Вказане свідчить про значні компенсаторні можливості нейтрофрілів, які здатні в умовах інтенсивного HBV навантаження підтримувати загальний баланс у фрагоцитарній системі.

3. Інтенсивність фрагоцитозу у хворих на ГГВ легкого і середнього ступеня тяжкості, що отримували симбіотик, була значно вищою, ніж за стандартної терапії, за рахунок збільшення кількості фрагоцитуючих нейтрофрілів у крові в 1,2-1,4 разу.

4. Використання симбіотика підвищує як інтенсивність фрагоцитозу, так і регулює поглинаючі можливості мікрофрагів у разі легкого ступеня тяжкості хвороби, а особливо в разі середнього ступеня, тим самим підтримуючи ФАН при ГГВ на оптимальному рівні.

\section{Література}

1. Silva M.T. Neutrophils and macrophages work in concert as inducers and effectors of adaptive immunity against extracellular and intracellular microbial pathogens / M.T. Silva // J. Leukoc. Biol. - 2010. - Vol. 87, N 5. - P. 805-813.
2. Neutrophils in the activation and regulation of innate and adaptive immunity / A. Mantovani, M.A. Cassatella, C. Costantini, S. Jaillon // Nat. Rev. Immunol. - 2011. - Vol. 11, N 8. - P. 519-531. 
3. Рабсон А. Основы медицинской иммунологии / А. Рабсон, А. Ройт, П. Делвз . - М.: Мир, 2006. - 320 с.

4. Защитные стратегии нейтрофильных гранулоцитов от патогенных бактерий / Б.Г. Андрюков, Л.М. Сомова, Е.И. Дробот, Е.В. Матосова // Здоровье. Медицинская экология. Наука. - 2017. - № 1(68). - .C. 4-18.

5. Christelle Gabriel. Neutrophils: neglected players in viral diseases / Christelle Gabriel, Zhisheng Her, Lisa F.P. // DNA Cell Biol. - 2013. - Vol. 32. - P. 665-675.

6. Holly M.K. Defensins in Viral Infection and Pathogenesis / M.K. Holly, K. Diaz, J.G. Smith // Annu. Rev. Virol. - 2017. - Vol. 4. doi 10.1146/annurev-virology-101416-041734.

7. Branzk N. Molecular mechanisms regulating NETosis in infection and disease / N. Branzk, V. Papayannopoulos // Semin. Immunopathol. - 2013. - Vol. 35, N 4. - P. 513-530.

\section{References}

1. Silva, M.T. (2010). Neutrophils and macrophages work in concert as inducers and effectors of adaptive immunity against extracellular and intracellular microbial pathogens. J. Leukoc. Biol. 87 (5), 805-813.

2. Mantovani, A., Cassatella, M.A., Costantini, C., \& Jaillon, S. (2011). Neutrophils in the activation and regulation of innate and adaptive immunity. Nat. Rev. Immunol., 11 (8), 519-531.

3. Rabson, A., Roit, A., Delves, P. (2006). Osnovy meditsinskoy immunologii [Fundamentals of Medical Immunology]. M. Mir. 320 [in Russian].

4. Andryukov, B.G., Somova, L.M., Drobot, E.I., \& Matosova, E.V. (2017). Zashchitnyye strategii neytrofilnykh granulotsitov ot patogennykh bakteriy [Protective strategies of neutrophil granulocytes from pathogenic bacteria]. Meditsinskaya ekologiya. Nauka [Medical Ecology. Science], 1 (68), 4-18 [in Russian].

5. Christelle Gabriel, Zhisheng Her, \& Lisa F.P. (2013). Neutrophils: neglected players in viral diseases. DNA Cell Biol. 32 (12), 665-675.

6. Holly, M.K., Diaz, K., \& Smith, J.G. (2017). Defensins in viral infection and pathogenesis. Annu. Rev. Virol., 4. doi 10.1146/annurevvirology-101416-041734

\section{PHAGOCYTIC ACTIVITY OF NEUTROPHILS IN PATIENTS WITH ACUTE HEPATITIS B}

\author{
M.M. Popov, A.I. Sklyar \\ I. Mechnykov Institute of Microbiology and Immunology of the
} National Academy of Medical Sciences of Ukraine, Kharkiv

SUMMARY. When penetrating inside organism infection agents meet resistance from innate immune cells, where phagocytes are the first to meet the agents.

The aim of the work - to study the polymorph nuclear neutrophils functional state in patients' blood for acute
8. The role of neutrophils in the development of liver diseases / Ruonan Xu, Huihuang Huang, Zheng Zhang, Fu-Sheng Wang // Cellular \& Molecular Immunology. - 2014. - Vol. 11, N 3. - P. 224-231.

9. Silva M.T. Neutrophils and macrophages: the main partners of phagocyte cell systems / M.T. Silva, M. Correia-Neves // Front. Immunol. - 2012. doi.org/10.3389/fimmu.2012.00174.

10. Busca A. Innate immune responses in hepatitis $B$ virus (HBV) infection / A. Busca, A. Kuma // Virology J. - 2014. - Vol. 11. - P. 1-8.

11. Lactobacillus rhamnosus GG Activation of Dendritic Cells and Neutrophils Depends on the Dose and Time of Exposure / S. Cai, M. Kandasamy, J.N., Rahmat [et al.] // J. Immunol. Research. - 2016 Pubmed ID: 27525288 : http://dx.doi.org/10.1155/2016/7402760.

12. Иммунный статус, принципы его оценки и коррекции иммунных нарушений / В.Г. Передерий, А.М. Земсков, Н.Г. Бычкова, В.М. Земсков. - К.: Здоров'я, 1995. - 211 с.

7. Branzk, N., \& Papayannopoulos, V. (2013). Molecular mechanisms regulating NETosis in infection and disease. Semin. Immunopathol. 35 (4), 513-530.

8. Ruonan Xu, Huihuang Huang, Zheng Zhang, \& Fu-Sheng Wang. (2014). The role of neutrophils in the development of liver diseases. Cellular \& Molecular Immunology, 11 (3), 224-231.

9. Silva, M.T., \& Correia-Neves, M. (2012). Neutrophils and macrophages: the main partners of phagocyte cell systems. Front. Immunol. doi.org/10.3389/fimmu.2012.00174.

10. Busca, A., \& Kuma, A. (2014). Innate immune responses in hepatitis B virus (HBV) infection. Virology J., 11, 1-8.

11. Cai, S., Kandasamy, M., Rahmat, J.N., Tham, S.M., Bay, B.H. Lee, Y.K., \& Mahendran, R. (2016). Lactobacillus rhamnosus GG Activation of Dendritic Cells and Neutrophils Depends on the Dose and Time of Exposure. J. Immunol. Research. Pubmed ID: 27525288 : http://dx.doi.org/10.1155/2016/7402760

12. Perederiy, V.G., Zemskov, A.M,. Bychkova, N.G., \& Zemskov, V.M. (1995). Immunnyy status, printsypy yego otsenki i korrektsii immunnykh narusheniy [Immune status, principles of its evaluation and correction of immune disorders]. Kyiv: Zdorovya [in Russian].

$H B V$ infection in varying degrees of severity in the dynamics of conventional treatment and after prescription of symbiotic.

Patients and methods. 108 patients with acute hepatitis $B$ were under observation. 56 men and 52 women with an average $34 \pm 1.9$ (from 18 to 69 years old). 17 healthy persons were included into a control group. In order to estimate phagocytic activity of neutrophils (PAN) phagocytic index of neutrophils (PIN) and phagocytic number of neutrophils (PNN) with incubation period of 30, 60 and 180 minutes were detected. 


\section{ОРИГІНАЛЬНІ ДОСЛІДЖЕННЯ}

Results. Significant activation of innate cellular components of the primary immunity during an active phase of HBV-infection was detected among patients with mild severity of acute hepatitis $B$. Thus, PIN and PHN were 1.1-1.8 times enlarged and 1.5-1.9 times compared to the control group accordingly.

As for patients with moderate severity, activity of phagocytosis was decreased. As a result the number of neutrophils that took part in phagocytic reactions was decreased as well (1.2-1.5 times compared to the control group). However, absorption capacity of neutrophils of patients was increased or set to a normal level.

Patients with both mild and moderate severities that took symbiotic had a higher level of intensity of phagocytosis compared to the patients that took a regular treatment with 1.2-1.4 times increasing number of phagocytic neutrophils in blood.

Conclusions. We can admit that compensatory possibilities of neutrophils are essential since they are able to maintain balance in phagocytic system in case of intensive HBV load. Including symbiotic to a regular therapy we can observe increasing of intensity of phagocytosis as well as regulation of absorbing potential of neutrophils among the patients with different serenity degrees of HBV infection.

Key words: acute hepatitis B; phagocytosis; phagocytic index of neutrophils; phagocytic number of neutrophils; symbiotic.

\section{Відомості про авторів:}

Попов Микола Миколайович - д. мед. н., професор ДУ «Інститут мікробіології та імунології ім. І.І. Мечникова Національної АМН України», м. Харків; imidir@ukr.net

Скляр Анатолій Іванович - аспірант, ДУ «Інститут мікробіології та імунології ім. І.І. Мечникова Національної АМН України», м. Харків; rmkh@ukr.net

\section{Information about authors:}

Popov M. - DMS, Professor of the State Institution «I. Mechnykov Institute of Microbiology and Immunology of the National Academy of Medical Sciences of Ukraine»; imidir@ ukr.net

Skliar A. - Postgraduate of the State Institution «l. Mechnykov Institute of Microbiology and Immunology of the National Academy of Medical Sciences of Ukraine»; rmkh@ukr.net

Конфрлікт інтересів: немає.

Author have no conflict of interest to declare.

Отримано 28.08.2017 р. 